Blaž VREČKO ILC, Zlatko ŠABIČ

\title{
AMERICAN ANTI-CHINESE RACISM DURING THE COVID-19 CRISIS AND ITS STRATEGIC FUNCTIONS
}

\begin{abstract}
The Covid-19 crisis that hit the USA especially hard was accompanied by intensified anti-Chinese racism fuelled by the anti-Chinese rhetoric used by the Trump Administration. Although Trump's political opponents blamed him for having mismanaged the pandemic response, the anti-Chinese stance was a bipartisan issue. The article aims to analyse anti-Chinese racism in its systemic and historical dimensions. It examines the nature and strategic utility of antiChinese racism for past, the Trump, and future administrations as well as for America's elites generally. It is shown that anti-Chinese racism was substantially transformed during the pandemic and above all utilised to address the general destabilisation of the US-dominated socio-political and socio-economic order both at home and globally. China's growing importance around the world and the potential domestic destabilisation of the US mean that the strategic utility of anti-Chinese racism may well remain important for some time to come.
\end{abstract}

Keywords: Covid-19 crisis, Trump's presidency, antiChinese racism, systemic racism, foreign policy

\section{Introduction}

The Covid-19 crisis that has hit the USA especially hard may be considered paramount in the line of crises the world witnessed following Donald Trump's election as the $45^{\text {th }}$ President of the United States of America. At the end of the Trump presidency, the total number of deaths caused by the virus was fast approaching the 400,000 mark. $^{1}$ Both at home and abroad, Trump will be remembered for his unusual individualistic approach to the presidency, for the incoherent domestic and foreign policy and, primarily, for studious ignorance of the spread of the Covid-19 disease. ${ }^{2}$ Contrary to his

* Blaž Vrečko Ilc, PhD, Assistant Professor, Faculty of Social Sciences, University of Ljubljana, Slovenia; Zlatko Šabič, PhD, Professor, Faculty of Social Sciences, University of Ljubljana, Slovenia. DOI: 10.51936/tip.58.specialissue.670-688

1 For data, see https://covidtracking.com/data/national.

2 In this article, the term "coronavirus" is also used. 
promises, America has not become 'Great Again' but is today more divided, unequal, internally destabilised, and dysfunctional (Chow and Warner, 2020). In this America, the intensification of various forms and expressions of racism has been prominent (Elias et al., 2020).

With the start of the Covid-19 pandemic, Asian-American communities experienced virulent racist attacks that were fuelled and legitimised by conspiracy theories about the origin of the coronavirus in a Wuhan laboratory and the rhetoric of the Chinese authorities' mismanagement of the pandemic (Gover, Harper and Langton, 2020). These 'theories' not only circulated on the far-right fringes of US society but were promoted by President Trump and his Administration, other prominent Republicans, and the conservative media (Siu and Chun, 2020). Even the liberal media and representatives of the Democratic Party, despite generally blaming Trump for having mismanaged the pandemic response, supported Trump in his vilification of China. The latter did not attract the usual uproar from the liberal establishment in the face of Trump's racist notions and practices (Lemoine, 2020a). In his electoral campaign, even Democratic presidential candidate and future president Biden relied on anti-Chinese discourse. Existing analyses come to various conclusions that explain bipartisanship in this regard. For example, some see the anti-Chinese discourses as an efficient electoral tool for Trump, which the Democrats then adopted (Chow and Warner, 2020; Cohen, 2019). Others believe such discourses are used as a device to cover over the mismanagement of the crisis response by Trump, Republicans, and Democrats (Christensen, 2020). Still others see these discourses as an expression of the successful institutionalisation of anti-Chinese stances by the Trump Administration which the whole political establishment has needed to adapt to (Zriek, 2020), and as a historically common response to a societal crisis linked to diseases/pandemics (Elias et al., 2020). These analyses importantly contribute to the literature on the anti-Chinese discourse, yet only partially address its systemic nature. Namely, they do not consider the societal, political and economic strategic functions it has played both historically and in the current Covid-19 crisis nationally and internationally. The existing literature chiefly views anti-Chinese racism as a historical exception, an institutional novelty introduced by the Trump Administration, or an irrational set of ideas and responses of ordinary citizens, groups, and elites during times of crisis. However, we argue that Trump's discourses and policies are not an aberration but are in fact a continuation of the anti-Chinese discourses and policies long present in the American context. We thus claim that a specific structure-based approach to understanding and analysing racism is needed if we are to comprehensively address the intensified and transformed antiChinese racism seen today. This approach would enable us to answer our central research questions: How (and if) was anti-Chinese racism intensified 
and transformed during the Covid-19 pandemic and what was, is and will be its strategic utility for the position held by America's elites at home and internationally during and after the pandemic?

The purpose of this article is therefore to address the lacuna in the literature by approaching anti-Chinese racism in such a way that would permit us to address the central question of anti-Chinese racism's intensification, transformation and its present and future utility for America's elites in their responses to the Covid-19 crisis and to the internal and international destabilisation of the American order that has intensified during this crisis.

The features, transformation and strategic functions of anti-Chinese racism will primarily be analysed on the domestic level, yet not at the expense of understanding its ramifications for the position America holds in the world. The USA is, after all, a superpower and its domestic practices have an impact on international relations. From the conceptual standpoint, we build upon the understandings of racism (Kundnani, 2014; McWhorter, 2009) and anti-Chinese racism (Turner, 2014; Vukovich, 2013) as a historically dynamic system that is constitutive of the genesis and adapts to the development and functioning of American society and the state, and its domestic and international policies. It is a mechanism for inscribing borders between the superior/normal/rational/healthy US individuals and US society on one hand, and Chinese individuals and society on the other, who are deemed to be inferior/abnormal/irrational/dangerous. It is multidimensional and encompasses virulent racist rhetoric and practices and subdued, rational-sounding discourses, practices, policies and institutions, including state strategies and policies that reinforce each other and draw from a similar historical archive of racist notions/practices. The anti-Chinese discourse has been created and utilised by America's elites for historically-specific strategic purposes like strengthening their positions of power by re-establishing cohesion and restabilising order in the context of the broader destabilising and transforming of society.

To ensure a comprehensive analysis of how anti-Chinese racism has intensified and transformed during the Covid-19 crisis and its strategic functions in both the national and international contexts, in the first part of the article we address the historical development and central characteristics of anti-Chinese racism as a constitutive system of the American republic. We focus on the historically developing discursive archive (ideas, stereotypes, prejudices) of anti-Chinese racism and its changing and expanding strategic functions. Following this, we consider the variety of forms of anti-Chinese racism concerning state policies, their rationalisations, and strategic functions. This enables us to establish a comprehensive framework for analysing the characteristics and transformations of anti-Chinese racism and its strategic utility today and in the future, both at home and internationally. 
Accordingly, in the second part we examine the domestic US context where we first address the intensified and transformed anti-Chinese racism concerning discourses and policies/practices under the Trump Administration. Second, we will examine the strategic functions these intensifications have served in the context of the Covid-19 crisis that have escalated the already destabilised US domestic order.

In the third part, attention is paid to the international context where we address the nature and strategic functions of anti-Chinese racism with respect to the (re)balancing of power in the international community and the geopolitical destabilisation exacerbated by the Covid-19 crisis. At the end, we add our take on the strategic relevance of anti-Chinese racism for the incoming Biden Administration and the elites in America generally, given the almost inevitable instances of domestic destabilisation and the perceived threat posed by China to the global dominance of the USA.

\section{Anti-Chinese racism: characteristics and development}

Anti-Chinese racism is viewed here as a multidimensional structure and, together with other dimensions of American racism (e.g. anti-Native American and anti-black), as being crucial for the development of the USA, its self-identification, its foreign and domestic policies, the trajectory of its capitalist economic system, and the US-dominated global structures and institutions (Calavita, 2007; Feagin, 2012; Goldber, 2002; McWhorter, 2009; Turner, 2014). Racism(s) were and are crucial for rationalising and obfuscating the discrepancies between the imagining and functioning of the American republic as a declarative liberal democracy, as a society of equal opportunities provided by the free market and as a benevolent anti-imperialist and anti-colonial force, and the reality of the Herrenvolk nature of its democracy, the racist nature of its market system (e.g. slavery) and its (neo) imperial policies (Feagin, 2012; Kundnani, 2014; McWhorter, 2009; Turner, 2014).

The dynamism and stability of this anti-Chinese racism is visible in historically changing discourses that retain the asymmetry in the relationship between the 'superior, benevolent US' and the 'inferior, aggressive and evil' China. Discourses (e.g. prejudices) from times past are never completely erased. They become part of the archive of anti-Chinese racism and can be reutilised in periods of major destabilisation of the US order (Vukovich, 2013). The archive is constantly adapting to historically dominant scientific/ folk theories and notions concerning the superiority or inferiority of various groups. The historical legitimacy of a specific racist discourse is a product of specific relations of power (McWhorter, 2009; Turner, 2014; Vukovich, 2013). 
The archive from which discourses on China draw includes certain notions about China and the Chinese as well as particular notions about the USA and 'proper' Americans in a relational way. Among the central historical notions about China are the notion of China being uncivilised and inferior, as having archaic and exotic customs, and religion, as having despotic political institutions and culture, not having a free market, and being technologically backwards. Such notions are always paired with the notion of the USA as being technologically and culturally superior, as moral, honest, as belonging to a superior race, as being a democratic, market-based society and respecting personal liberties, and as being an exceptional, enlightened redeemer nation (Turner, 2014; Vukovich, 2013; Feagin, 2012).

Notions of China as constituting a threat also form part of the archive. These can take many forms, from a cultural threat, to "the yellow peril" that imagines the Chinese as a biological threat, as a threat to the well-being of the white, normal, healthy, and biologically superior American nation (Calavita, 2007; Turner, 2014). This can also take a technological/scientific variation in the form of the fictional character Dr Fu Manchu, which established China as a dangerous entity populated by a devious, cruel and cunning Eastern race, whose leaders are brilliant, immoral and dangerous men, 674 a threat to the very survival of the West (Siu and Chun, 2020; Turner, 2014). After the 1949 Communist Revolution, another variation to emerge was the "Red China" threat, entailing a mix of the anti-communist notion of "the red menace" and the idea of "the yellow peril". China is constituted here as a threat to proper civilisation represented by the USA, as an abnormality that must be stopped. Chinese communism is implicitly established as a disease promulgated by the Communist Party of China (CPC), seen as an evil institution that prevents China from the normal, universal path of civilisational development leading to a liberal democracy. The Chinese are framed as a nation of communist automatons incapable of resisting their evil overlords while the large Chinese population is used as a tool to provoke anxiety among Americans (Svetličič, 2020; Turner, 2014; Vukovich, 2013).

Like with other dimensions of American racism, the state has played a central, but not an exclusive role in the genesis of anti-Chinese racism (McWhorter, 2009). Such racism was established jointly by political, economic and intellectual elites, and the central state and private institutions including the state bureaucracy, and the media which produced specific truths about China that became a matter of common sense for most Americans (Calavita, 2007; Turner, 2014; Vukovich, 2013). Anti-Chinese racism has always been utilised by the elites in the USA for historically changing and/or expanding specific domestic and international strategic functions.

Since starting in the mid-19th century, anti-Chinese racism has been fundamental in legitimising particular forms of American imperialism that have 
obfuscated imperialist policies by firmly positioning the USA as a benevolent force (Turner, 2014). It has been central to the consolidation of the American state and its principal actors, for strengthening and transforming American identity, and establishing internal cohesion especially in times of crisis by strongly limiting resistance to the exploitative nature of the socioeconomic order (Vukovich, 2013). It has covered over the internal differences, exploitation, discriminations, and the hierarchical inclusions among ascribed members of the white category (Calavita, 2007). Similarly to the anti-black and other dimensions of American racism, it has prevented intraethnic and inter-class solidarities in the national context by re-aligning interests among unequal groups of the white racial category by imagining the Chinese as a threat and by implementing policies to discriminate against them (Lee, 2003; A. Ong, 1996). It has also prevented post-colonial solidarity among the Asian-Pacific states by justifying aggressive containment policies towards China (Turner, 2014).

When talking about the pre-Trump period and pre-Covid-19, one should not disregard the status of anti-Chinese racism before 2016. For example, the "pivot to Asia" policy introduced by the Obama Administration did not change the previous anti-Chinese policies (Turner, 2016), nor was there any change concerning the core strategic functions of anti-Chinese racism. We should also not forget that the American order was already in deep demise, creating a perfect context for the Trump presidency's intensification of antiChinese racism (see Bacevich, 2020). This led to the emergence of more antiChinese discourses that (re-)constituted China as a specific racial threat and as a rising "non-white/Western" (super)power. China's potential to offer an alternative development paradigm was seen as an attack on the hegemony of the USA (Siu and Chun, 2020). This transformation of anti-Chinese racism established a particular way of seeing China's future development as inevitable. It shaped a reality in which certain responses to the threat seemingly posed by China might be perceived as unavoidable to prevent the imagined defeat of the USA and the destabilisation of the imagined, rule-determined and orderly international system (Turner, 2014). China was established to be a destabilising force in global affairs. It became a scapegoat for the USA's socio-economic problems at home. Simultaneously, the USA was affirmed to be the benevolent defender of the values and rules of the international system (Turner, 2016). The Trump Administration built on these transformations of anti-Chinese racism and further intensified them, above all, via a trade war that included a new set of anti-Chinese policies and anti-Chinese discourses. 


\section{Anti-Chinese racism: intensification and transformation during the Covid-19 crisis}

The way anti-Chinese racism has intensified and transformed during the Covid-19 crisis must be understood in the context of the pre-Covid-19 'innovations' introduced by the Trump Administration with regard to anti-Chinese policies. In 2018, it launched a trade war that substantially worsened the US-Sino relationship which, in turn, added to the anti-Chinese racism (Chow and Werner, 2020; Itakura, 2019). In this context, novel racist policies have been institutionalised and then implemented, such as a new restrictive visa policy targeting Chinese nationals, the FBI's crackdown on ChineseAmerican scientists based on racial profiling, the banning of Chinese technology corporations, and pressuring of Western countries to do the same (Chan, 2020; Siu and Chun, 2020; also see Feng 2019). These policies were justified by discourses that imagined all Chinese people as potential agents of the CPC and hence as dangerous for US national security. This renewed the "Red China" threat and the notion of the Chinese being soulless communist automatons who lack the capacity for autonomy, are incapable of resisting the inherently evil institution of the $\mathrm{CPC}$, and are tools of the communist

676 state. The discourse also renewed the image of China and the Chinese as a yellow peril, and as Dr Fu Manchu('s), brilliant, technologically-advanced, immoral men bent on crushing the West and securing world domination.

During the Covid-19 crisis, Trump's existing anti-Chinese policies and 'novel' forms of anti-Chinese racism were further justified and expanded through a novel, harsh anti-Chinese corona narrative promulgated by the Trump Administration and its allies that racialised the virus through terms like "the Chinese virus" and "Kung Flu". This had a big impact by way of intensifying anti-Chinese sentiment among the American public and substantially influencing the political and media narratives in the USA and other Western states. The racist corona narrative centred on three dimensions:

- the origin of the disease;

- the eating habits of the Chinese; and

- the response of the Chinese authorities (Darling-Hammond et al., 2020; Lemoine, 2020b).

As concerns the virus' origin, a conspiracy theory promoted by Trump and the media stated that the coronavirus was manufactured at the Wuhan Institute of Virology, from where it leaked. It was based on the scientifically false premise that the virus leaping from animals (bats) to humans was improbable and that the high virulence of the virus could only be achieved artificially (Lemoine, 2020a). This 'theory' was uniquely useful in depicting China as a nefarious source of disease by establishing a naturalised, 
inextricable and inherent causal link between China as being bent on world domination via science and technology and the origin of the virus, while also giving a basis for those demanding that China pay for the global pandemic.

The second dimension of the racist narrative focused on the eating habits of the Chinese because the Wuhan wet market was identified as the most likely origin of the virus. The eating habits of the Chinese were imagined as unnatural, dirty and exotic, thereby re-legitimising the notion of exotic China and the hierarchy between the 'superior' and 'normal' US diet and the 'strange' and 'exotic' Chinese diet. The racist nature of this lies in the fact that only the Chinese are singled out for eating 'strange' animals and having live animal markets, while Americans are absolved for basically doing the same thing (Cho, 2020). The racist condemnation of the diet and hygiene in China successfully masks the larger global systemic causes tied to industrialisation, urbanisation, industrial food production and global warming that have increased the frequency of zoonotic pandemics (Davis, 2020).

The third dimension of the narrative concentrated on the response of the Chinese authorities. The narrative claimed that Chinese authorities had covered up the situation and delayed notification of the outbreak and for having continuously underreported the number of dead (Siu and Chun, 2020). This narrative recreated racist images of the Chinese communist leadership as despotic, evil, disregarding of human lives, and a threat to proper (Western) civilisation by preventing the normal functioning of state institutions and them responding to the pandemic. Here, China as 'the Red menace' notion and the older notion of Chinese 'Asiatic despotism' were mixed together. From the perspective that the PRC managed to contain the first wave of the pandemic while the USA and most other Western states were failing in that respect, we can observe the inherently racist nature of this part of the narrative (Lemoine, 2020b).

Such a corona narrative precipitated 'novel' forms of anti-Chinese racism, such as the violent attacks on members of Asian-American communities most prominently appearing in the late 19th century. The attacks targeted not only the Chinese-American community but various Asian-American communities. The perceived 'right' phenotype was enough to provoke an attack (Elias, Ben, Mansouri and Paradies, 2021). Racist harassment of these communities reached levels unseen since the Second World War and was shown to be linked to the novel racist corona narrative promulgated by Trump and his allies as well as the intensification of existing anti-Chinese policies (Darling-Hammond et al., 2020; Chow and Werner, 2020). 


\section{Strategic functions of anti-Chinese racism during the pandemic}

The trajectory of anti-Chinese racism during the pandemic should be understood as being inextricably connected with the specific strategic functions for which it was utilised by the Trump Administration, its allies and America's elites generally. This trajectory was inextricably connected with various long-term and immediate political, economic and geopolitical destabilisations of the American republic in its domestic and global settings. On the most superficial level, anti-Chinese racism was instrumentalised as an electoral tool by both Trump's re-election campaign and by the Democratic establishment to refocus the blame for mismanagement of the crisis response onto China (Christensen, 2020). The Trump Administration also used it to mask the fact that it had dismantled the institutional infrastructure that was in place to successfully address future pandemics (Chow and Werner, 2020; Davis, 2020). Still, the bipartisan nature of its utilisation runs much deeper. As mentioned, it is inherently connected with the response of the elites to domestic and global destabilisations that endanger the existing socio-political, economic, geopolitical arrangements in the sense of their cohesion, stability, legitimacy, functioning and even their existence.

In the US domestic context, the pandemic laid bare the nature of America's socio-political and economic system and radically opposed it to the central national (self-)mythologisation of the American republic as the model society. The pandemic and its (mis)management have worsened the well-being of the poor as well as of minority communities, with both already having suffered under the neoliberal policies of past decades (Elias et al., 2021). In other words, Trump's handling of the pandemic response betrayed the hopes of those who had voted for him in the expectation of a more prosperous future, yet the inability to address poverty is common to both Republicans and Democrats, and their political, economic and intellectual elites. Along with other western elites, they have established a modern, hyper-globalised form of capitalism. The latter has enabled them to accumulate vast profits by taking advantage of the highly-skilled, modestly paid, yet highly motivated workforce in (especially) China. This has radically weakened the power of organised labour in the USA. It has destroyed American communities built around stable manufacturing jobs. It has also led to the retrenchment of the welfare state, the privatisation of public services, and increasing healthcare and higher education costs, thereby enabling a radical, upward wealth transfer to the rich (Harvey, 2005). As mentioned, the pandemic has exacerbated the latter trend; wealthy Americans have prospered in the extreme while the majority has suffered. Their suffering is directly related to the existing labour and social policies and the condition of the healthcare system in which services are prohibitively expensive, making 
people avoid seeing a doctor and receiving medical treatment (Davis, 2020). The management of the pandemic under Trump is a good illustration of a state incapable of helping its citizens, save for the richest among them.

These destabilisations posed a substantial risk to the existing order and the elites in America had to strategically respond to it. Anti-Chinese racism was utilised to re-establish and re-consolidate societal cohesion and order and to re-legitimise and stabilise the existing socio-political and economic arrangements, stratifications, and hierarchies. It deradicalised and racialised the (potential) revolt and resistance of most Americans against the existing order by refocusing their frustrations from the elites onto a 'common foreign enemy'.

The anti-Chinese racism has become obsessed with re-mythologising the USA and re-consolidating the American collective identity and its nationalistic ideology by renewing and intensifying one of its central operations: functioning according to stark double standards. The purpose of the multidimensional implementation of double standards is to rationalise certain racist domestic, foreign, military and geopolitical policies while simultaneously masking the problematic aspects of the USA's domestic and foreign policies. The internalisation of these double standards among the American public is crucial for the American domestic context and for US policies on the global level. On this level, the double standard functions as one of the primary instruments for establishing a Manichean division between the benevolent and good USA on one side, and the aggressive, evil, destabilising, and rulebreaking China on the other (Turner, 2014). China is seen as a threat and a problem due to the despotic and depraved nature of its government that is indifferent to saving lives and is more interested in suppressing the 'truth'. In turn, the USA is portrayed as uniquely capable of addressing the pandemic, although its policies have become a victim of the authoritarian, secretive and nefarious Chinese regime, and the victim of its benevolent nature and the democratic and freedom-loving character of its society that is based on general respect for citizens' and human rights (see Lemoine, 2020b).

Such a double-standard discourse has clearly obfuscated not only the incompetence of US elites in managing the crisis and the USA's poor public health capabilities but also masked the policies/practices of US authorities that were similar to those ascribed to the Chinese authorities: censoring and threatening medical experts, punishing whistle-blowers, confiscating medical equipment intended for other countries, initiating lockdowns, implementing state-sponsored, privacy-breaching tracking apps (NCAC, 2020). These double standards further obfuscated the central nature of the existing American system that deems the economy paramount and the well-being of the population secondary. Importantly, albeit not unexpectedly, the remythologisation of the USA and denigration of China have made their way 
from the domestic to the foreign policy sphere, too. It became obvious in this policy sphere that while the anti-Chinese discourse may have been strongly connected with the Trump presidency, it would be unlikely to end after Trump departed the White House.

\section{The impact of anti-Chinese racism on US foreign policy}

\section{The Trump presidency}

The main characteristic of Trump's presidency in the context of the intensified anti-Chinese racism is easy to identify: anti-Chinese sentiment is present, with Trump showing no hesitation to help spread it across the world. A good example of this attitude is a conference Trump held on 18 March 2020, when a journalist asked him why he kept calling Covid-19 the "Chinese virus", "despite reports that dozens of incidents of bias against Chinese Americans who have been blamed for allegedly spreading the coronavirus" and "ethnicity does not cause the virus" Trump's laconic answer, repeated three times was: "Because it comes from China", and that his use of the term "is not racist at all" (YouTube 2020). In September 2020, at a regular session of the General Assembly of the United Nations, Trump mentioned China no less than 11 times, specifically referring to the "China virus" that "has claimed countless lives in 188 countries". ${ }^{3}$ He added that the world "must hold accountable the nation which unleashed this plague onto the world: China", which, among other things, "locked down travel domestically while allowing flights to leave China and infect the world". ${ }^{4} \mathrm{He}$ also explained in this speech why the USA had decided to withdraw from the World Health Organisation: because the latter "is virtually controlled by China".

The openly racist discourse by Trump at the international level does not come out of thin air - it is driven by anxieties, also in academic literature, about the impact of the steadfast economic growth China has enjoyed over the past four decades. Offensive realists, for example, are suspicious of China's 'intentions'. They do not believe in China's peaceful rise. They argue that "Washington is likely to go to considerable lengths to prevent China from becoming too powerful" (Mearsheimer, 2010: 385). Warnings about China's disrespect of global norms and values in particular regarding human rights may be heard at various levels, not just in the USA. For instance, the Human Rights Watch (HRW) states that "China's government sees human rights as an existential threat", and that its reaction

3 The text of the address is accessible at https://rumpwhitehouse.archives.gov/briefings-statements/ remarks-president-trump-75th-session-united-nations-general-assembly/, 14. 4. 2021.

4 Ibid.

5 Ibid. 
could pose an existential threat to the rights of people worldwide ... if not challenged, Beijing's actions portend a dystopian future in which no one is beyond the reach of Chinese censors, and an international human rights system so weakened that it no longer serves as a check on government repression. (Roth, 2019)

The concerns held by the HRW are of course purely normative, not political, but in this context and in the eyes of Trump's government they could be easily abused to serve Trump's anti-Chinese agenda. After all, the USA promotes itself as a defender of the oppressed (e.g. the Uyghur minority) and as a staunch supporter of democracies (Taiwan), although it is well known that the USA has a long history of systematically breaching human rights both at home and abroad (Kundnani, 2014).

As much as widespread criticism of China may be justified, there is no (and must not be any) space for racist-like rhetoric in the international fora. The Trump Administration may have been able to galvanise hatred against China among the domestic public, as a recent public opinion poll shows (Silver et al., 2020). Yet it has mostly been unsuccessful in exporting the stigmatisation of China as the culprit for the pandemic currently ravaging the world. The survey included 14 countries from around the world and shows that China is seen as having done a bad job at handling Covid-19, but not as bad as the USA (ibid.). In the context of his isolationist foreign policy, Trump accomplished nothing but a large "credibility gap" (Yarhi-Milo, 2018: 68). To borrow from Trump's vocabulary, the anti-Chinese racism prompted by the Trump Administration has, by and large, hit a wall - the majority of UN member states are not impressed. In the global discourse, the terms "China virus" or "Wuhan virus" are not normally used instead of the common name given to the pandemic: Covid-19.

Still, China's autocratic regime, gross human rights violations and its mistreatment of minorities all remain a problem, not only for the USA but for many other countries around the world as well, even to the point that states are willing to resist China's great attractiveness as a trading partner. A case in point is the recent forging of an alliance that Western democracies struck with the USA against China's record of human rights abuse, such as the EU's statements on the prospects of stronger economic cooperation with China demonstrate. In a June 2020 statement, President of the EU Council Michel and President of the European Commission von der Leyen expressed their concern about the "deteriorating human rights situation [in China], including the treatment of minorities in Xinjiang and Tibet, and of human rights defenders". Nevertheless, they said that "Engaging and cooperating with China is both an opportunity and necessity" (CoEU, 2020), which by the end of 2020 led to an agreement on a long-negotiated investment deal with 
China. ${ }^{6}$ Yet, just a few months later, the EU joined in the global sanctioning of China for its human rights abuses, which might threaten that deal (CoEU 2021; Blenkinshop, 2021). Importantly, this action has been initiated by the USA under its new leader, President Joe Biden, who made no secret during his presidential campaign that China would be seen by his administration as a systemic competitor for global power, meaning that one must be prepared for both cooperation and confrontation.

\section{The Biden presidency}

The Biden Administration is of course aware that China's development today is a latent challenge to the USA's structural power (Strange, 1988; Malkin, 2020). Little wonder that Biden's scepticism about the relationship between the USA and China ${ }^{7}$, and the bipartisan support for many of Trump's anti-Chinese policies, have not altered since moving to the White House. Some authors remind that Biden used to be quite supportive of China in the past. ${ }^{8}$ But times have changed.

We believe that Biden's policy on China shall be driven by interlinked domestic and international challenges originating from the most populous country and possibly soon to become the most powerful country in the world. Biden's relationship with China must be considered in the context of Trump's remarkable ability to embed the anti-Chinese racism in the American public and even to institutionalise it in the most virulent forms. The popularity of the anti-Chinese discourse should also be seen in the context of its utility for America's elites for addressing and managing the competition of China that could endanger their domestic and global position.

Starting in 2020, Chinese scientists namely published more peerreviewed papers in the natural sciences than US scientists (Ishikura, 2020). Chinese state and private MNCs have also systematically begun to acquire ever larger portfolios of various patents and substantially increase their R\&D in the most advanced technology fields (e.g. 5G, robotics, high-speed rail) where they are becoming important players in the setting of technological standards (Malkin, 2020). This could prove problematic for the USA. Its global economic dominance rests on the ascendancy of US MNCs of global

6 Details about the deal accessible at https://trade.ec.europa.eu/doclib/press/index.cfm?id=2115, 14 . 4. 2021

7 See, for example, Biden's political advertisement at https://www.washingtonpost.com/video/ politics/joe-biden-for-president-unprepared-campaign-2020/2020/05/14/ec602523-306c-4fe6-8340311ea381d7f7_video.html, 14.4.2021.

8 One Republican Trump devotee even went as far as to claim that Biden's new policy on China would be a 180-degree turn for Biden, because he "was more responsible than any other legislator of the post-Nixon era for enabling China's rise as a revisionist superpower" (Grenell, 2020). 
value chains in the form of their concentration of market power and their dominance of the global market for intellectual property assets (Panitch and Gindin, 2012; Seaman, 2020). Creation and control over key technologies are critical for Washington to keep up the general profitability and the power of the US economy. America's tech MNCs control the world wide web and the basic Internet infrastructure, which permits them not only to realise enormous profits (Moore and Tambini, 2018; CompTIA, 2021) but to have vital strategic control over communication lines. The potential success of Chinese MNCs to break this leverage of the USA and reduce the global predominance and control of key IP of the US MNCs would hold serious consequences for Washington, especially the Pentagon. The USA's military power relies heavily on close cooperation between US tech giants and the US state security apparatus (Levine, 2018). Snowden's revelations demonstrated the extreme capabilities held by the US state to surveil. The US state can access a foreign country's crucial communication infrastructure. An infrastructure supplied by Chinese firms would make this almost impossible while giving the PRC similar capabilities (Fernandes, 2020). The trajectory of Chinese development would also have a broadly negative effect on the USA's ideological power. The loss of control of online platforms and their technologies would greatly reduce their abilities to shape public opinion, silence or censor anti-establishment opinions and manufacture broad consent for the existing order (Herman and Chomsky, 2012; Spencer, 2018).

Given the narrowness of Biden's victory, the Biden Administration's priorities focusing on restoring the pre-Trump status quo, the militancy (e.g. storming of the US Capitol) and the size of Trump's supporters, as well as addressing the issues that matter to Americans much more than foreign policy, such as the growing inequality, poverty, life expectancy, private debt, unemployment precipitated by the pandemic, and the continuation of the Black Lives Matter protest movement and the oppressive responses of the police and security forces, one cannot imagine a considerable turn in Washington with respect to China, all the more so if Beijing, besides its economic challenges to the USA, opts to keep being aggressive to pursue the accomplishment of its foreign policy goals. Losing out to China in so many ways could further weaken the USA's domestic stability and the legitimacy of its economic and political system. That would further erode the cohesion of society and legitimacy domestically and undermine the USA's global hegemony. These are only some of the reasons which suggest that anti-Chinese racism will remain under the Biden Administration, not only for domestic consumption but in the foreign policy domain as well. 


\section{Conclusion}

In view of the escalation of the USA-China relationship during the Trump presidency and the intensification of potent forms of anti-Chinese racism domestically during the Covid-19 pandemic, the article sought to analyse the systemic and strategic nature of anti-Chinese racism. It addressed questions concerning the transformation of American anti-Chinese racism at the time of the Covid-19 crisis under the Trump Administration and its present and future (post-Trump) strategic functions. In this context, we first reflected on the bipartisan nature of anti-Chinese racism during the pandemic since Trump's racist anti-Chinese discourse and policies were not only supported by his allies but also by the Democrats, who joined in despite blaming Trump for having mismanaged the pandemic response. We argued in support of an analytical framework that would build upon the structure-based understanding of anti-Chinese racism we developed in the first part of the article. This analytical framework gives a more comprehensive picture of the complexity and multidimensional nature of American anti-Chinese racism and helped discern its transformation in the present context. It enabled us to reflect on the roles that anti-Chinese racism as a structure played and is playing in the transformations and functioning of the American society and state, its foreign and domestic policies, and its collective identifications. Moreover, it assisted in identifying, understanding and comprehensively addressing the multiple strategic functions for which it was and is being utilised by America's elites in the domestic and international contexts especially in times of crisis and destabilisation of the societal order. In this setting, we first analysed the characteristics and historical development of anti-Chinese racism in the USA where we showed its systemic and multidimensional nature (ranging from popular negative representations of China to restrictive immigration policies and aggressive US international policy) and its specific strategic utility for America's elites during a crisis and in substantial transformations of the US domestic and international order. The analysis demonstrated that anti-Chinese racism was relied on in previous historical contexts as a mechanism the elites utilised to, among others, refocus popular anger and re-establish socio-political and socio-economic cohesion and solidarity in periods of serious destabilisation and delegitimation of the US order (e.g. economic crises, rising inequality and poverty) and/or reimagining its role and mission on the global stage (e.g. from an anti-colonial to a colonial force).

In the second part, we focused on the US domestic and international context today as concerns the transformation of anti-Chinese racism. Drawing on insights from the first part, we identified and analysed various expressions of the intensification of anti-Chinese racism at home and 
in the international context during the Covid-19 crisis under the Trump presidency, ranging from harsh racist attacks on Asian-Americans, the racist corona narratives, the unprecedented trade war with China, the restrictive visa regime for Chinese nationals through to general surveillance of ChineseAmerican scientists and banning Chinese technological corporations from operating in the USA. We discerned the central strategic functions for which anti-Chinese racism was and is being employed by America's elites during the pandemic. The analysis revealed that anti-Chinese racism was utilised to address the substantial instances of socio-political, politico-economic and geopolitical destabilisation that threatened the dominant position held by America's elites. Such anti-Chinese racism was relied on in the domestic context to re-establish and re-consolidate societal cohesion and order and to re-legitimise and stabilise the existing socio-political and economic arrangements, stratifications and hierarchies. It deradicalised and racialised the revolt of many Americans against the current order by refocusing their anger onto a 'common enemy'. In the international context, it was utilised to address the perceived threat of China's global dominance over the USA. In the final part, we focused on the future relevance of anti-Chinese racism for the incoming Biden Administration and America's elites generally. Drawing on insights arising from the previous analytical steps, we predict that the potential further domestic destabilisation at home in the USA and China's actual, potential and perceived threat to the USA's global technological, economic, military and political dominance means that the strategic utility of anti-Chinese racism could become even more important. Hence, antiChinese racism may well remain a prominent part of the USA's domestic as well as international political discourse and policies for some time to come.

\section{BIBLIOGRAPHY}

Bacevich, A. (2020): The Age of Illusions. New York: Metropolitan Books.

Blenkinshop, P. (2021): EU-China deal grinds into reverse after tit-for-tat sanctions. Reuters, 23 March. Accessible at https://www.reuters.com/article/us-eu-chinatrade-idUSKBN2BF276, 14. 4.2021.

Bromowich, D. (2019): American Breakdown. London: Verso.

Calavita, K. (2007): Immigration Law, Race, and Identity. The Annual Review of Law and Social Science 3 (1): 1-20.

Chan, V. (2020): The U.S. has nailed Chinese companies this year. Why hasn't Beijing retaliated? Fortune. Accessible at https://fortune.com/2020/09/17/uschinese-companies-china-beijing-restrained-response/, 14. 4. 2021.

Cho, J. (2020): Why It's Wrong (and Racist) to Blame Covid-19 on Chinese 'Wet Markets'. FAIR. Accessible at https://fair.org/home/why-its-wrong-and-racist-toblame-covid-19-on-chinese-wet-markets/, 14. 4. 2021.

Chow, T. and J. Werner (2020): The US-China Trade War. New York: Rosa Luxemburg Stiftung. 
Christensen, T. J. (2020): A Modern Tragedy? Covid-19 and US-China Relations. Brookings Policy Brief.

Cohen, W. I. (2019): America's Response to China: A History of Sino-American Relations. Columbia University Press.

Darling-Hammond, S., E. Michaels, A. Allen, D. Chae, M. Thomas, T. Nguyen, ... R. Johnson (2020): After "The China Virus" Went Viral: Racially Charged Coronavirus Coverage and Trends in Bias Against Asian Americans. Health Education and Behaviour 47 (6).

Davis, M. (2020): The Monster Enters Covid-19, Avian Flu and the Plagues of Capitalism. London: OR Books.

Elias, A., J. Ben, F. Mansouri and Y. Paradies (2021): Racism and Nationalism during and beyond the Covid-19 Pandemic. Ethnic and Racial Studies 44 (5): 783-793.

Feagin, J. R. (2012): White Party, White Government: Race, Class, and US Politics. New York: Routledge.

Feng, E. (2019): FBI Urges Universities To Monitor Some Chinese Students and Scholars in the U.S. NPR. Accessible at https://www.npr.org/2019/06/28/ 728659124/fbi-urges-universities-to-monitor-some-chinese-students-and-scholars-in-the-u-s, 14. 4. 2021.

Fernandes, C. (2020): The China Divide. Arena (4): 52-67.

Gover, A. R., S. B. Harper and L. Langton (2020): Anti-Asian Hate Crime During the Covid-19 Pandemic: Exploring the Reproduction of Inequality. American Journal of Criminal Justice 45 (4): 647-667.

Grenell, R. (2020): What's Biden's real China policy? Unlike Trump, he's done a 180. The Hill, 25 September. Accessible at https://thehill.com/opinion/ international/518115-whats-bidens-real-policy-on-china-unlike-trumps-its-hardto-know, 14. 4. 2021.

Harvey, D. (2005): A Brief History of Neoliberalism. Oxford; New York: Oxford University Press.

Herman, E. and N. Chomsky (2012): Manufacturing Consent. New York: Random House.

Ishikura, T. (2020): Study: China now leads the world in natural science papers. The Asahi Shimbun, 12 August. Accessible at http://www.asahi.com/ajw/articles/13629338, 14. 4. 2021.

Itakura, K. (2019): Evaluating the Impact of the US-China Trade War - Itakura 2020 - Asian Economic Policy Review - Wiley Online Library. Asian Economic Policy Review.

Kundnani, A. (2014): The Muslims Are Coming! London: Verso.

Lee, E. (2003): At America's Gates: Chinese Immigration during the Exclusion Era, 1882-1943. Chapel Hill: The University of North Carolina Press.

Lemoine, P. (2020a): The China Syndrome Part I: Outbreak. Quillette, August. Accessible at https://quillette.com/2020/08/24/the-china-syndrome-part-i-outbreak/, 14. 4. 2021.

Lemoine, P. (2020b): The China Syndrome Part II: Transmission and Response. Quillette, August. Accessible at https://quillette.com/2020/08/29/the-china-syndrome-part-ii-transmission-and-response/, 14. 4. 2021. 
Levine, Y. (2018): Surveillance Valley. Cambridge: Perseus Books.

Malkin, A. (2020): The Made in China Challenge to US Structural Power: Industrial Policy, Intellectual Property and Multinational Corporations. Review of International Political Economy 1-33.

Mearsheimer, J. J. (2010): The Gathering Storm: China's Challenge to US Power in Asiat. Chinese Journal of International Politics 3 (4): 381-396.

McWhorter, L. (2009): Racism and Sexual Oppression in Anglo-America: A Genealogy. Bloomington: Indiana University Press.

Moore, M. and D. Tambini (2018): Digital Dominance: The Power of Google, Amazon, Facebook, and Apple. Oxford: Oxford University Press.

Ong, A. (1996): Cultural Citizenship as Subject-making: Immigrants Negotiate Racial and Cultural Boundaries in the United States. Current Anthropology 37 (5): 737-762.

Panitch, L. and S. Gindin (2012): The Making of Global Capitalism. London: Verso.

Roth, K. (2019): China's Global Threat to Human Rights. Human Rights Watch World Report. Accessible at https://www.hrw.org/world-report/2020/countrychapters/global\#, 14. 4. 2021.

Seaman, J. (2020): China and the New Geopolitics of Technical Standardisation. Accessible at https://www.ifri.org/sites/default/files/atoms/files/seaman_ china_standardization_2020.pdf, 14.4.2021.

Silver, L., K. Devlin and C. Huang (2020): Unfavorable Views of China Reach Historic Highs in Many Countries. Global Attitudes \& Trends, Pew Research Center, October. Accessible at https://www.pewresearch.org/global/2020/10/06/unfavorable-views-of-china-reach- historic-highs-in-many-countries/, 14. 4. 2021.

Siu, L. and C. Chun (2020): Yellow Peril and Techno-orientalism in the Time of Covid-19. Journal of Asian American Studies 23 (3): 421-440.

Spencer, K. A. (2018): A People's History of Silicon Valley: How the Tech Industry Exploits Workers, Erodes Privacy and Undermines Democracy. London: Eyewear Publishing.

Strange, S. (1988): States and Markets London: Pinter Publishers.

Svetličič, M. (2020): From Red Scare to Yellow Peril: Reality and Fears of the Rise of China. Teorija in Praksa 57 (1): 347-367.

Turner, O. (2014): American Images of China. New York: Routledge.

Turner, O. (2016): China, India and the US Rebalance to the Asia Pacific: The Geopolitics of Rising Identities. Geopolitics 21 (4): 922-944.

Yarhi-Milo, K. (2018): After Credibility: American Foreign Policy in the Trump Era. Foreign Affairs 97 (1): 68-77.

Vukovich, D. (2013): China and Orientalism: Western Knowledge Production and the PRC. New York: Routledge.

\section{SOURCES}

CompTIA (2021): Cyberstates 2020. Accessible at https://www.cyberstates.org/, 14. 4. 2021.

CoEU (2020): EU-China Summit: Defending EU interests and values in a complex and vital partnership. Press release by President Michel and President von der 
Leyen, 22 June. Accessible at https://www.europarl.europa.eu/cmsdata/209405/ EU\%20Council_Press\%20release_22nd \%20EU-China\%20Summit_22.6.2020.pdf, 14. 4. 2021.

CoEU (2021): EU imposes further sanctions over serious violations of human rights around the world. Press release, 22 March. Accessible at https://www.consilium. europa.eu/en/press/press-releases/2021/03/22/eu-imposes-further-sanctionsover-serious-violations-of-human-rights-around-the-world/, 14. 4. 2021.

NCAC (2020): Free Expression During the Coronavirus Pandemic: Timeline. Accessible at https://ncac.org/news/free-expression-during-the-coronavirus-pandemic-timeline, 14. 4. 2021.

YouTube (2015): Donald Trump Says "China". Accessible at https://www.youtube. com/watch?v=RDrfE9I8_hs, 14.4.2021.

YouTube (2020): President Donald Trump: Calling it the 'Chinese virus' is not racist at all, it comes from China. Accessible at https://www.youtube.com/ watch?v=dl78PQGJpiI, 14. 4. 2021. 